Dalibor JOVANOVSKI

UDK: 616.921.5-036.22

Review article

\title{
THE SPANISH FLU PANDEMIC - A LESSON NOT LEARNED
}

\begin{abstract}
The Covid-19 pandemic that began last year inevitably prompted scientists to look back at the last major Spanish flu pandemic that occurred a century ago, sweeping across the globe and contributing to massive human losses from which some nations had to recover. Much like today, the threat of the Spanish flu was initially underestimated, most likely due to the hostilities happening as a result of WWI. The War ended, but the virus evolved from an epidemic to a major, unprecedented pandemic. Authorities reacted slowly to the spread of the flu, and the health system was completely unprepared to deal with the new and unknown danger. At first, even doctors, virologists, and epidemiologists could not come to terms with the type of virus they were dealing with. However, as the pandemic spread, the world adapted to the new conditions. States and local authorities introduced a series of restrictive measures to prevent the spread of the virus, hygiene measures were tightened, and there were orders for the mandatory wearing of masks, as well as the closure of shops, and cultural and educational institutions. There are many points that are similar from the time of the Spanish flu pandemic to today's conditions related to Covid-19. Just as it had unexpectedly appeared in 1918, the Spanish flu disappeared in 1920. It took scientists more than a decade after the end of the pandemic to discover the cause of the outbreak, but even today there are still many unknowns related to the Spanish flu.
\end{abstract}

Keywords: pandemic, virus, Spanish flu, measures, vaccine

$* * *$

It is clear to Spanish flu pandemic researchers that the Spanish flu was special in terms of its expansion and strength. The flu had spread to North America and Europe, but it had also spread surprisingly into the wilds of Alaska and the most remote islands of the Pacific. It is estimated that about 50 million people were infected with the virus, which at the time would equal one-third of the world's population (Tauenberger, 2006: 90). Influenza as a virus was not unknown before the 1918 pandemic. Hippocrates provided a good description of this virus in antiquity. According to statistics and analyses, from the year 1173 up to the outbreak of the Spanish flu, there had been 27 epidemics and pandemics that covered various parts of the world (Johnson, 2006: 15). But none were so transmissible and so deadly. 


\section{The origin and name of the virus}

The place of origin of this virus is still unknown today, despite the fact that it was called the "Spanish flu" in 1918 (Tauenberger, Morens, 2010: 19). There are various opinions as to how the virus appeared in the United States, China, or Europe, the main fronts on which military operations were conducted during WWI. When it is said that the virus originated in China, it often coincides with the opinion that previous experiences with the outbreak of influenza were most often associated with the Far East (Radusin, 2012: 813). There are scholars who still claim that the virus that caused the Spanish flu pandemic originated in China. Reportedly, Chinese workers traveling to France during WWI might have been the cause of the spread of the virus, as it had already existed in their country (Langford, 2003: 473). The proponents of the theory that the virus originated in China are relying on the presence of respiratory disease in the second half of 1917 in China's northern parts, which contained elements of both Spanish influenza and the plague, spreading rapidly (Hamphries, 2014: 80). The existence of a Chinese hospital that treated workers from this country who were in France is also taken as evidence that the virus originated in China. A deadly, virus-like respiratory illness had emerged among the Chinese workers at the hospital. However, research shows that the origin of the flu cannot be accurately determined. Thus, the British scholar John Oxford believes that the disease first appeared in a British military base in France during the winter of 1916 (2001: 1857-1859). Speaking of British military forces on the Western Front, it should be noted that as early as March 1918, military doctors and pathologists had noticed that the soldiers had a mild, but rapidly spreading fever (Bresalier, 2013: 101). Erkoreka believes that the mixture of soldiers, animals, and 24 types of poisonous military gases used on the Western Front could be the cause of an epidemic, which would later turn into a pandemic (2009: 191). On the other hand, the American Barry hypothesized that the outbreak of the Spanish flu occurred in the Haskell area, in the state of Kansas, in early 1918. He based his claim on the testimony of a local doctor, Loring Miner, who was well acquainted with previous types of influenza that differed from what he had been seeing in a growing number of patients, especially the emergence of increasing mortality. (Radusin, 2012: 813).

The name of this virus was given quite by accident, despite the fact that Spain was not the source of this severe infectious disease. The country did not take part in WWI, and the local press was not under any censorship when it came to writing about the emergence and development of a new type of flu. Thus, in the daily newspaper $A B C$, on May 22, 1918, an article appeared on the existence of a flu-like virus. One week later it was announced that King Alfonso XIII, the Spanish Prime Minister, and several other members of the government had contracted the new virus, so the pandemic was termed the Spanish flu (Radusin, 2012: 812). In this regard, it is interesting to note that during the same period, the Fabra agency sent a telegram to Reuters about the strange occur- 
rence of an epidemic virus. In addition to the name the 'Spanish virus', it was sometimes referred to as the 'Spanish Lady' (Trill, Trilla, Daer, 2008: 668). It is interesting to note that in Spain this virus was originally called the 'Neapolitan soldier' (Soldado de Napoles). This name originated from the musical operetta La cancion de olvido (A Song of Oblivion), which was performed during the first wave of the dangerous and unknown virus (Tsoukalas, Kousoulis, Sgantzos, 2016: 24).

Apart from the name the 'Spanish flu', in the literature we can also find the French name for it, 'La grippe', which was used in the French city of Rouen due to the appearance of this hitherto unknown virus (Tsoukalas, Kousoulis, Sgantzos, 2016: 23). This was probably due to the fact that the virus resembled the seasonal flu. But it is also interesting to note, and this influenced the development of the virus, that until early August 1918, British doctors, epidemiologists, and virologists did not classify the new virus as influenza, but as Pyrexia of unknown origin. (Bresalier, 2013: 102-103).

\section{The development of the pandemic}

Medical staff, virologists, and epidemiologists of this period, for the first time, were battling several waves of a flu-like epidemic. Unlike ever before, there were three major and extremely deadly waves during the Spanish flu epidemic. The first wave, which swept across Europe, North America, and Asia, occurred during military operations during WWI, from March to April 1918. The second wave took place in the period from September to November 1918, and the last strong wave appeared at the beginning of 1919 (Tauenberger, 2006: 90). It should be noted that the second wave was much deadlier than the first, and was due to a mutation in the virus, causing millions of deaths (Erkoreka, 2009: 190). Here we would like to mention an interesting opinion. In Russia, due to the October Revolution and the Civil War that followed, this event, along with the foreign war intervention, no research was conducted on the Spanish flu pandemic, but it is interesting to note that according to the researchers in Russia there was no third wave (Морозова, О.М, Трошина, Морозова Е.Н., Морозов A.H, 2021: 103). Some believed that the first wave of the Spanish flu was more like a benign seasonal flu, much like what occurred each year, causing low mortality among those infected (Erkoreka, 2009: 193). Unlike the pandemic of 18901891, which took months for the flu virus to spread worldwide, the Spanish flu spread much faster and simultaneously to several continents. That was probably the reason for the high mortality rate. Of course, we should not forget that the appearance of this type of flu coincided with the military conflicts of WWI, which certainly had an impact on the relationship of medicine as a science, but also on virology and epidemiology.

It is interesting to note that in the Balkans, more precisely on the Macedonian front, there are data on the occurrence of the Spanish flu among Serbian soldiers. The military doctor Aleksandar Radosavljevic noticed that in April of 
1918, hundreds of Serb soldiers came down with an unusually strong virus that caused severe pneumonia and even death in some of the soldiers, but also in civilians. According to him, the reason for the emergence of what would be called the Spanish virus was the contact of Serbian soldiers with a French baker (Radusin, 2012: 813). However, when it comes to the Serbian army, according to Krivoshijev, on the island of Corfu, in the background there were cases of soldiers being infected with the new virus. The first deaths due to lung complications were registered in June and July (Кривошијев, 2020: 14). This was undoubtedly related to the presence of foreign armies on the Macedonian front. Unfortunately, there is not much data on how many people were infected with this virus. Apart from the information provided by Radosavljevic about the occurrence of a pandemic among Serbian soldiers, among which there must have been mobilized Macedonians, we can find some data in the medical analyses of British doctors, who were part of the British military units on the Macedonian front. However, those data also refer only to soldiers, while we have data on the general populace. According to the British reports, the virus had already appeared in the summer of 1918, which later caused great mortality among the soldiers who had already suffered from malaria and cholera (Phear, 1920: 9092). After the collapse of the Macedonian front, we can note that there was a hospital in Veles that housed the infected Serbian soldiers (Кривошијев, 2020: 15). At the end of October 1918, the commander of the Entente forces that broke through the Macedonian front, Louis Franchet d'Espèrey, arrived in Skopje. He wrote in his Memoirs that there were many sick and dead from the Spanish flu in the city ( $\lambda^{\prime}$ Епере, 2018: 113). We do not have accurate data on the numbers of infected and dead in Serbia at that time, as the country had just been liberated from Austro-Hungarian, German and Bulgarian occupation. According to a report by the British Ministry of Health, the health system of the country, which was almost non-existent, was in a terrible state. Hospitals were in a desperate state, completely unprepared to receive patients (Reports, 1919: 260). A similar situation was taking place in defeated Bulgaria, where no information was received about the spread of the Spanish flu (Reports, 1919: 261). In Greece, whose territory housed a part of the Macedonian Front, the newspaper Thessaly published information on June 30,1918, about the presence of the Spanish flu on Greek territory, while on August 23, the Ministry of the Interior released the first piece of information about the new virus (K $\alpha \varrho \alpha \chi \alpha \lambda\llcorner$, 2009: 37-39). Unlike Serbia and Bulgaria, we have some data on the number of deaths. In Thessaloniki, for example, in the period from September to December 1918, 1,164 people died as a result of this virus, while in Athens and Piraeus, 1,619 inhabitants succumbed (Reports, 1919: 259-260).

In the more developed countries involved in the greatest military conflict in world history to that date - WWI, then known as the Great War - it became clear that the public health system was completely unprepared for the Spanish flu pandemic (Saunders-Hastings, Krewski, 2016: 5). One of the major problems the public health system faced during the pandemic was the overcrowded hos- 
pitals, as well as a shortage of medical staff, who were also affected by the pandemic. Hospitals had to extend the working hours of their medical staff, call on students for help, and postpone other medical services, all in order to deal with the new and dangerous virus (Schoch-Spana, 2001: 33). The health authorities also called for help from retired doctors and nurses, and help was sought from all those who had some experience in caring for the sick.

The first analysis of the number of victims of the Spanish flu pandemic was made by Edwin Jordan during the 1920s. According to his estimates, the number of victims of this pandemic was about 21,500,000 people (Johnson, Mueller, 2002: 108). Today, according to more accurate data and analysis, the number of victims is estimated at more than $50,000,000$ people, although this number is not final, either.

Today, when American scientists write about a large number of victims of the Spanish flu, they emphasize that the number of deaths from this virus exceeds American losses in WWI, WWII, as well as in the Korean and Viet Nam wars (Radusin, 2012: 813).

In the UK, the death toll from the Spanish flu was also higher than in previous pandemics. According to official data from 1920, in England and Wales, the mortality rate was $4.774 \%$ per 1,000 patients, while in Scotland the mortality rate was 4.3\% (Johnson, 2006: 69).

The virus caused high mortality rates on other continents, too. People were experiencing a real tragedy. Some remote Eskimo settlements were simply halved or even disappeared completely (Cevtinić, Savić, 2018: 135). A similar thing occurred in Africa. According to the data, $4 \%$ of the inhabitants of the South African port of Cape Town died as a result of the Spanish flu, while in the Mexican state of Chiapas the number of deaths was 10\%. In Japan, 300,000 people died. From the analyses of the death toll per 1,000,000 inhabitants, we can conclude that this number is far higher on the African continent and in Asia than in Europe and North America (Johnson, Mueller, 2002: 110-114). The sources are full of terrible data about the daily happenings on the streets, trains, homes. In the South African port of Cape Town, a train driver reported six deaths from the flu in just five kilometers by train, and in Australia, a doctor listed 26 funeral processions in one street in just one day (Tsoneva, Hristova, 2018: 164). However, scientists noted that despite the fact that the virus had spread to all continents, with dire consequences for the population, the prevailing impression was that it had spread more to Europe, Asia, and North America (Tsoukalas, Kousoulis, Sgantzos, 2016: 24). This shows that more research needs to be done to show that that pandemic was devastating to all of humanity. This also applies to research in Macedonia.

The mortality of the Spanish flu also brought about demographic changes. Thus, in Spain, the country after which the virus was named, in 1918 the population mortality rate was the highest throughout the XX century. In the same year, the population growth in Spain was negative due to the high mortality rate from influenza (Trilla, A., Trilla, G., Daer, 2008: 672). This was logical, 
bearing in mind that up to 1,200 people died daily in the second largest Spanish city, Barcelona (Tsoneva, Hristova, 2018: 164). The pandemic was the largest demographic shock experienced by mankind.

\section{Measures to protect the population and prevent the spread of the virus}

Authorities in various countries around the world took steps to prevent the spread of the raging Spanish flu pandemic. In the United States, authorities noted that the virus spread en masse due to the presence of the population in public places. Seeing this, the health authorities tried to apply social distancing measures on an unprecedented scale (Tomes, 2010: 48). However, the measures did not yield great results and this was acknowledged by the health authorities. A special problem was the ban on public gatherings, as well as the closure of some institutions and bars, which was not followed by the complete closure of all bars and, therefore, there were problems and complaints by those who were closed. The state closed down schools, and quarantine was introduced. Certain Catholic priests, such as those in New Orleans, rebelled against the closure of churches (ibid.). Measures taken by the authorities to close cinemas and theaters led to a reduction or loss of income of those engaged in these activities, although people themselves had begun to avoid going to cinemas and theaters (Koszarski, 2005: 467). However, as time went on, some of the theaters managed to get permission to reopen, while others reopened on their own initiative, having suffered major financial problems (ibid.). Yet the closures, permissions to work, and the self-inflicted violations of the law differed from city to city, and from state to state. For example, according to Kosharski, the city of New York never completely closed down cinemas and theaters (ibid.). The state also launched a campaign through public media to raise public awareness of the dangers of the Spanish flu. Brochures were published, and comics and cartoons were printed. Work was also done to raise awareness for greater personal hygiene of the population. It was especially emphasized that coughing, sneezing, and spitting present a serious danger in spreading the virus. It was emphasized that contact between people, especially those who were infected, was a major cause of the spread of the virus. And that was one of the lessons learned from this pandemic in the United States.

In the Balkans we had Serbia, which experienced enormous human and material losses during WWI, also struck by the virus that caused huge problems and many deaths. The Serbian military doctor Aleksa Savic warned that one of the reasons for the rapid spread of the virus, apart from the hostilities that ended in late 1918, was the gathering in groups in refugee camps, barracks, factories, etc. (Савић, 1918: 5). He proposed measures to stop the spread of the virus as quickly as possible. According to him, the sick should not come into contact with others, they should not go to places where there were gatherings of people, such as cinemas, theaters, schools, cafes. Special attention should be paid to personal hygiene, with a special emphasis on the hands, throat, and nasal cavities. 
Similarly to the United States, he suggested caution with coughing, sneezing, but also, as he emphasized, the national sport - spitting. He also suggested the wearing of masks by the medical staff, as well as the wearing of scarves by everyone else. In Greece, in October of 1918, the Ministry of the Interior banned public gatherings, closed down schools, and recommended maintaining good hygiene and avoiding contact with anyone who showed symptoms of the virus (Tsoukalas, Kousoulis, Sgantzos, 2016: 24).

Similar measures were taken in Italy and Portugal. Immediately after the outbreak of the new virus, schools and public buildings were closed down, but this was not always accepted by the educational institutions. The role of the media in Italy was also interesting, as reports on the development of the virus and the death rate led to conflict situations. This could not pass without consequences. Italy's largest daily newspaper, the Corriere della Sera, was forced by the civilian authorities to stop reporting on the rise of Spanish flu deaths, as it caused public uncertainty and created panic (Tinotti, 2013: 257).

Public events where a large number of people gathered were canceled. A sports match was to be held in Paris, with an expected attendance of 10,000 people. City officials canceled it to prevent the further spread of the virus (ibid.). Regarding France, it should be mentioned that from the very beginning of the pandemic, the mayor of Lyon, Édouard Herriot, understood the importance of maintaining high levels of hygiene and so he ordered the regular disinfection of trams, banned public gatherings, organized quick funerals, and ordered mixing holy water with antiseptics in the churches (Tsoukalas, Kousoulis, Sgantzos, 2016: 24).

Australia, although a remote and isolated continent, faced the new Spanish flu virus in March of 1919. Like the other countries, Australia, still a part of the British Empire, i.e. under the authorities there, tried to prevent the spread of the virus through certain measures such as the closure of schools, theaters, churches, pubs. It is also interesting to note that the streets of Australian cities were sprayed, and the population was obliged to wear masks in public places, as well as to pay attention to hygiene (Curson, McCracken, 2006: 105). Authorities were also forced to impose a quarantine, as well as strict controls on entry into Australian territory. The media played a major role in tackling the new pandemic. This, in turn, as in other countries, provoked a reaction from the citizens.

The various measures imposed by the state and the local authorities did not go unnoticed by the citizens who, although threatened, did not always respect the measures, and even resisted them. An Anti-Mask League was formed in San Francisco to protest against the mayor's decision to make masks mandatory (Dolan, 2020: 1-28). Its activities involved the lawyer and suffragette E. C. Harrington, known for her advocacy for civil and women's rights. The movement against wearing masks led to some interesting situations. Some theater administrators at the end of the pandemic were reluctant to force visitors, actors, and musicians to wear masks, while others feared being accused of supporting those who publicly opposed wearing masks (Koszarski, 2005: 468). 
The attempts of the states to restrict the movement and gathering of the population with certain measures caused resistance, but also emotional and psychological trauma. We can see this even in the official gazettes of the states in question. In Srpske novine, the official newspaper of the Kingdom of Serbia, an article on the Spanish flu emphasized that the virus had disrupted the established customs and traditions of the people. It was emphasized that people kept away from each other, stopped greeting each other, saw enemies in friends, and instead of kindness, fierce unkindness was recommended (Српске новине, 1918: 3). In this regard, we can note that there were cases when shop assistants forbade customers from entering the stores, and the whole transaction took place outside, in the open (Tsoneva, Hristova, 2018: 164).

Lifestyle changes and restrictions imposed by the authorities did not stop the spread of the pandemic. The researchers concluded that all the measures taken by the central and local authorities were delayed and uncoordinated, and in the parts of the world affected by the War, the measures were impractical, especially since the movement of military units contributed to the spread of the virus (Tinotti, 2013: 257).

The Spanish flu is still considered the deadliest pandemic in human history (Tauenberger, Morens, 2010: 19). According to the analyses done, one of the consequences of the flu was the great impact of mortality rates on the economic processes in the countries (Garren, 2007: 20). In addition to the economic problems caused by the Spanish flu pandemic, there were health consequences for those who survived the flu, such as schizophrenia, diabetes, strokes, and heart attacks. Today, analyses are still carried out on the effects of the Spanish flu on people and their lives. It is increasingly concluded that this virus caused something previously unthinkable. The majority of deaths from the Spanish flu during 1918, according to data obtained by scientists, were caused by secondary bacterial pneumonia. What was surprising was the high mortality rate among young people, who had not previously suffered so much from other types of flu (Tauenberger, 2006: 91). There was a particularly high mortality rate during 1918 among young people aged 20 to 40, characterized by rapid death within a few hours of coming down with the virus (Tsoneva, Hristova, 2018: 161).

According to the analyses, it can be concluded that this virus affected everyone regardless of class, gender, race, nation, with all its consequences (Johnson, 2006: 96). Among those who died of the Spanish flu were the French poet Guillaume Apollinaire, the German sociologist Max Weber, Sophie Freud, the daughter of Sigmund Freud, the French playwright Edmond Rostand. Some survived, such as the French General Joseph Joffre, and the future US President Franklin Delano Roosevelt (Tsoukalas, Kousoulis, Sgantzos, 2016: 26). Krivosheev also notes a paradox, especially in Serbia. Although urban areas were more affected by this pandemic, mortality was higher in rural areas due to the lower cultural level of the population in rural areas, their way of life, and the poorly developed hygiene and health culture (Кривошејев, 2020: 25). 
Much can be written about the outbreak of the Spanish flu and its spread, as well as the question of the measures taken to prevent its spread and the reaction of the public against them. However, one thing that can be noticed is that it is the same as today's dangerous Covid-19 situation: the underestimation of the danger of the virus at the very beginning of its occurrence, as well as during the waves of its spread. As we noted above, one of the views on its occurrence is that it originated in the United States. It is very interesting to note that in this country, at the beginning of the spread of the virus, not enough attention was paid to it. Thus, in the prestigious Journal of the American Medical Association, the spring wave was not even recorded in the index of the journal (Tsoukalas, Kousoulis, Sgantzos, 2016: 24). The following examples speak of the underestimation of the danger of the new virus, at least in the United States. At the beginning of the epidemic, which turned into a pandemic, in this country, many of the areas that were not affected, at that point, by the new dangerous virus, considered it a simple nuisance, not a deadly disease. So, in some newspapers, it could be read that the Spanish flu was probably just flu with a little tomato sauce on it (Dicke, 2015: 199). But tomato sauce has proven to be a terrible joke in underestimating the dangers of the new virus. The danger was realized too late, as it was, and so the public health services across the United States lost weeks in terms of organization, resulting in many deaths (Dicke, 2015: 200).

\section{Seeking a cure for the virus}

The rapid development of the Spanish flu prompted scientists to look for a way to create a vaccine for the virus, which had been hitherto unknown in history in terms of both severity and high mortality. Research shows that doctors initially had difficulty diagnosing the new virus, often making the mistake of thinking the affected had a common cold, cholera, or the bubonic plague. In addition to the problems that arose with the (mis)diagnosis of the virus, doctors also prescribed the wrong therapy, which led to the death of the patients. Thus, the use of aspirin during the height of the 1918 pandemic proved to be particularly toxic, causing high mortality rates, especially among the young (Starko, 2009: 1409). However, the rapid development of the virus, its mutation, and high mortality necessitated a rapid search for a cure for it. Louis Pasteur's experiences and discoveries, which helped to deal with other diseases, quickly began to be used. At first, it was mistakenly believed that this type of flu was caused by Pfeiffer bacteria, but soon a study by French scientist Charles Gilles Henri Nicole revealed that the flu was, in fact, caused by a small microorganism that could not be seen by research tools at the time (Radusin, 2012: 813). Even today, when there is a flu vaccine, some researchers believe that the virus is still a mystery.

Attempts were made in Australia to produce a vaccine using saliva mucus, as well as a combination of streptococci and staphylococci (Curson, McCracken, 2006: 105). This attempt failed. Similar attempts were made by the 
British army, whose health services had an interesting argument about what kind and what type of vaccine should be used, and whether two doses were needed for complete protection (Bresalier, 2013: 113-122).

The actual discovery of the virus known as the Spanish flu did not happen until after the end of the Spanish flu pandemic. British scientists Wilson Smith, Christopher Andrews, and Patrick Laidlaw were able to isolate the virus in 1933, using the success of the American virologist Richard Shope, who had, two years previously, isolated and identified swine flu (Johnson, 2006: 21). Johnson believed that the late detection and isolation of influenza, or influenza virus, was due to a number of factors, such as technical reasons, difficulties in culturing influenza virus, but also the use of Koch's postulates and practical results in the bacteriology of Louis Pasteur and Joseph Lister; they were an obstacle to the search for viruses (ibid.). However, the use of new electron microscopes made it possible to see the virus, and in that direction, in 1935, Frank McFarlane Barnett cultured the virus in a chicken egg (Tsoukalas, Kousoulis, Sgantzos, 2016: 26). With all this advancement in technology, medicine, and virology, in the late 1930s and early 1940s, medical science finally reached its desired goal - the flu vaccine. The success was due to the parallel efforts of Jonas Salk and Thomas Francis, who managed to make a flu vaccine (Saunders - Hastings, Daniel Krewski, 2016: 6).

The discovery of the flu vaccine did not mean that scientists at the time knew the source and type of virus that had caused the global Spanish flu pandemic. It was not until 1995 that a group of scientists, using archival materials, began a more detailed study to discover the genomic structure of the Spanish flu (Željko Cvetinić, Vladimir Savić, 2020: 137). After some research, they discovered that the Spanish flu pandemic was caused by the H1N1 influenza A virus. According to them, the source of this virus almost certainly originated from birds, and waterfowl are a reservoir for all known influenza viruses (ibid.). However, has the mystery of the Spanish flu really been solved? I am not a doctor or a virologist. That is why I will note the opinion of Garcia-Sastra and Whitley, who believe that despite the great discoveries, the virulence of the virus that caused the great human tragedy is still unclear (Garcia-Sastra, Whitley, 2006: 5127). According to them, questions remain about the antigen, pathogenicity, and immunity to the virus that caused the largest pandemic in history (ibid., 5130). Similarly, Morens and the now well-known Fauci, in a study on the Spanish flu, noticed that many questions about the virus have not yet been answered, especially about its origin, unusual epidemiological features, and causes of death (Morens, Fauci, 2007: 1018-1019). This shows that no matter how advanced science and technology are, man still cannot find answers to many questions that arise from past epidemics and pandemics. We have noticed in this study that many things from the Spanish flu pandemic are similar to today's Covid-19 pandemic, and here lies one of the answers to the many questions that arise from what is happening to us today. For now, however, nature is stronger than man. 


\section{References}

Д’Епере, Ауј Франше, 2018, Мемоари. Солунски фронт, Србија, Балкан, Прометеј, Нови Сад

Савић, Алекса, 1918, Инфлуенца, Војна штампарија, Солун

Сриске новине, г. LXXXV, бр. 126, 23 октобра 1918

Кривошејев, Владимир, 2020, Шпанска смрт: Прилог проучавања последице пандемије шпанске грознице у Србији, Културна похиса, г. XVII, (2020), бp.43, 11-28

Морозова, О.Н, Трошина, Т.И., Морозова, Е. Н., Морозов, А.Н., 2021, Пандемия испанки 1918 года в Росии. Вопросы 100 лет спустя, Journal of Microbiology, epidemiology and immunobiology, 95-106

Bresalier, Michael 2013, Fighting flu: Military pathology, vaccines and the conflicted identity of the 1918-1919 pandemic in Britain, Journal of the History of Medicine and Allied sciences, v. 68/1, 87-128

Curson, Peter, McCracken, Kevin, 2006, An Australian perspective of the 19181919 Influenza pandemic, NSW Public Health Bulletin, v. 17/7-8, 103-107

Cvetinić Željko, Savić Vladimir, Prije 100 godina španjolski grip „majka“ svih pandemija poharala je svijet, Vetrinarska stanica, v. 49-5, 2018

Dicke, Tom, 2015, Waiting for the flu: Cognitive inertia and the Spanish influenza pandemic of 1918-1919, Journal of History of Medicine and Allied Sciences, v. $70 / 2,195-217$

Dolan, Brian, 2020, Unmasking history: Who was behind Anti-Mask League protests during the 1918 Influenza epidemic in San Francisco, Perspectives in Medical humanities, 1-28

Erkoreka Anton, Origins of the Spanish Influenza pandemic (1918-1920) and its relation with the First World War, Journal of Molecular and Genetic Medicine, v. 3/2, 2009

Garcia-Sastra, Adolfo, Whitley, Richard, J., 2006, Lessons learned from reconstructing the 1918 Influenza pandemic, The Journal of infectious diseases, $v .194,5127-5132$

Garren, Thomas, 2007, Economic effects of the 1918 Influenza pandemic. Implications for a Modern-day pandemic, Federal Reserve Bank, St. Louis, November

Humphries Mark Osborne, Paths of infection: The First World War and the Origins of the 1918 Influenza pandemic, War in History, v. 21/1, 2014

Johnson Niall, Mueller Juergen, Updating the Accounts: Global mortality of the 1918-1920 "Spanish" Influenza pandemic, Bulletin of the History of Medicine, 76/1, 2002

Johnson Niall, Britain and the 1918-19 Influenza pandemic. A dark epilogue, Routledge, London \& New York, 2006

Koszarski, Richard, 2005, Flu season: "Moving picture world" Reports on Pandemic influenza, 1918-1919, Film History, v. 17/4,466-485

Langford Christopher, 2003, Did the 19181-19 Influenza Pandemic originate in China?, Population and Development Review, v. 31/3, 
Morens, David M., Fauci, Anthony S., 2007, The 1918 Influenza pandemic: Insights for $21^{\text {st }}$ Century, The Journal of Infectious Diseases, v. 195/7, 10181028

Oxford J.S., The so-called great Spanish influenza pandemic of 1918 may have originated in France in 1916, Philos Trans Soc. Lond. B. Biol Sci 356, 2001

Phear, Arthur G., 1920, Medical experiences in Macedonia and Caucasus, Occasional lecture, March, 26,

Radusin, Milorad. The Spanish flu - Part I: the first wave, Vojnosanitetski pregled, 69/9, 2012

Reports on Public Health, 1919, v. 4, Ministry of Health, London

Saunders - Hastings Patrick R., Krewski Daniel, Reviewing the History of Pandemic Influenza: Understanding patterns of emergence and transmission, Pathogens, 66/5,2016

Schoch - Spana Monica, "Hospital's full - up": The 1918 Influenza Pandemic, Public Health Report, v. 116/2, 2001

Starko, Karen, 2009, Salicylates and Pandemic influenza mortality. 1918-1919 Pharmacology, Pathology and Historic evidence, Clinical infectious diseases, v. 49/9, 1405-1410

Tauenberger Jeffrey K., 2006, The origin and virulence of the 1918 "Spanish" influence virus, Proceedings of the American Philosophical Society, v. 150/1, 2006

Tauenberger Jeffrey K., David, Morens M., 2010, Influenza: The one and future pandemic, Public Health Reports, v. 125/3

Tinotti Eugenia, Lessons from the History of Quarantine, from Plague to Influenza A, Historical review, 19/2, 2013

Tomes Nancy, "Destroyer and Teacher": Managing the mass during the 19181919 influenza pandemic, Public Health reports, v. 125, 2010

Trilla, Antoni, Trilla Guillem, Daer, Carolyn, 2008, The 1918 "Spanish Flu" in Spain, Clinical Infectious Disease, v. 47/5

Tsoneva, Lilyana, Hristova, Irina, 2018, Spanish flu pandemic, in: Karaganova Irina, Konstantinova Daniela (ed.), Health promotion and Social work, health care. Proceedings, v. 57, series 8.4, University of Ruse, 161-165

Tsoukalas, Gregory, Kousoulis, A., Antonis, Sgantzos, N. Markos, 2016, The 1918, Spanish Flu Pandemic, the origins of the H1N1-virus strain, a Glance in History, European Journal of Clinical and Biomedical Sciences, $v$. 2(4), 23-28

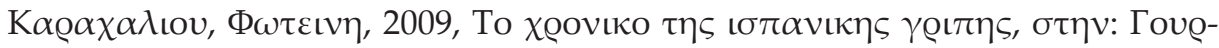

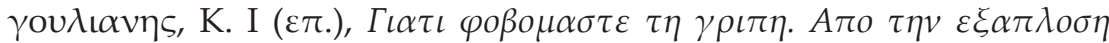

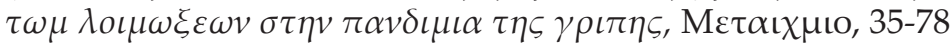

